\title{
Development of the Pre-Professional Identity of Vocational Students during Their Training through a Program Based on OER-Enabled Pedagogy and an Online Community of Practice
}

\author{
Fulgencio Sánchez Vera ${ }^{1}$ (D), Anastasia Tellez Infantes ${ }^{2}$ (D) , Javier Eloy Martínez Guirao ${ }^{3}$ (D) \\ and Fina Antón Hurtado ${ }^{3, *(\mathbb{D})}$ \\ 1 Departamento de Sociología y Antropología, University of La Laguna, 38670 La Laguna, Spain; \\ fsanchev@ull.edu.es \\ 2 Departamento de Ciencia Sociales y Humanas, Miguel Hernandez University, 03202 Alicante, Spain; \\ atellez@umh.es \\ 3 Departamento de Ciencia Política, Antropología Social y Hacienda Pública, Universidad de Murcia, \\ 30100 Murcia, Spain; j.eloymartinez@um.es \\ * Correspondence: fmanton@um.es
}

Citation: Sánchez Vera, F.; Tellez Infantes, A.; Martínez Guirao, J.E.; Antón Hurtado, F. Development of the Pre-Professional Identity of Vocational Students during Their Training through a Program Based on OER-Enabled Pedagogy and an Online Community of Practice. Sustainability 2022, 14, 356. https:// doi.org/10.3390/su14010356

Academic Editors: Julio

Ruiz-Palmero and

Melchor Gómez-García

Received: 21 November 2021

Accepted: 27 December 2021

Published: 29 December 2021

Publisher's Note: MDPI stays neutral with regard to jurisdictional claims in published maps and institutional affiliations.

Copyright: (c) 2021 by the authors Licensee MDPI, Basel, Switzerland. This article is an open access article distributed under the terms and conditions of the Creative Commons Attribution (CC BY) license (https:/ / creativecommons.org/licenses/by/ $4.0 /)$.

\begin{abstract}
Online professional communities based on sharing under open licenses have become a new way of building knowledge, learning and professional development of the participants who build and expand their professional identity in the new global space. These new dynamics of cyberculture are not being sufficiently explored in the training of vocational students. However, open pedagogy models can foster pre-professional identity, influence academic success and self-perception, as well as contribute to the commons. In this study, we have investigated from the anthropological perspective, the impact of a training program based on an open pedagogy model. Specifically, we have investigated the effect on the pre-professional identity and the academic results of vocational students, as well as on the development of the commons of their profession. Methodologically, we have combined the bibliographic review with the empirical, quantitative, and qualitative data, collected in the ethnographic fieldwork carried out during two academic years on 77 students of "Microcomputer Systems and Networks", in a vocational center located in the Community of Valencia (Spain). The results indicate that this methodology promotes, among students, the development of pre-professional identity, a better understanding of copyright and open licenses, appreciation of the documentation processes of their tasks, and the value of their works for society.
\end{abstract}

Keywords: vocational training; open pedagogy; OER-enabled pedagogy; Open Educational Resources (OER); pre-professional identity

\section{Introduction}

Vocational Education and Training (VET) in Spain has steadily increased its status and value over the past four decades. In addition, the changes and improvements in the VET model have had a broad consensus among all the actors involved (companies, union representatives, and education and labor administrations), and surprisingly, even when education has been since the beginning of democracy a battlefield among political parties, regarding vocational education, there has been a broad consensus [1]. However, this success may be short-lived if we forget about the new challenges of vocational training in an increasingly digitized, globalized, changing, and competitive world.

The growth of cyberspace and the different expressions of cyberculture have been possible thanks to the possibilities of interconnection, organization of people in virtual communities and, what is more important, the expansion of collective intelligence [2,3]. For Pierre Lévy, cyberculture is built on an axiom: "no one knows everything, everyone knows something, all knowledge is in humanity. There is no reservoir of transcendent knowledge 
and knowledge is none other than what people know" [4] (p. 10). Indeed, collective intelligence has come from hunter-gatherer societies; what is new today is cyberspace, and what must be achieved is to resolve the question of how, through it, we can be and act more intelligently. This has technical and organizational implications for articulating online communities [5], but also educational and ideological, because there are different ways of being and collaborating that can be articulated.

In the case of open online professional community models, participants freely come together to create common goods, which are available to all. The common goods, the practices used, and the results obtained are the three elements that define the commons, a governance model for the common well-being that allows the community to produce and manage tangible and intangible goods and resources that belong to all of us or, rather, resources that do not belong to anyone. It is a legal-philosophical concept, which in recent years, has regained validity and public repercussion, thanks to free software, the opensource movement, Creative Commons licenses, and the academic works of the Nobel Prize winner in Economics, Elinor Ostrom, for her contribution to the understanding of the government of the commons [6,7].

The practices of online professional communities follow a P2P (Peer to Peer) production model, which refers to networks between equals, where each individual or group collaborates with others in the achievement of a common goal [8,9]. Consequently, the commons are the source of knowledge and the resources of the community, and everything produced from it is returned to the commons, which is created and recreated, connected, and reconnected, by the members of the community, in a way which is constant and continuous.

The commons places us in a humanist framework, in which, issues that the neoliberal model has left aside, such as transparency, equity or universal access gain new legitimacy. It proposes a possible alternative to the market economy, from which to re-integrate the economic and the ethical, the individual and the collective. It is a model that relies on communities structured on trust [10].

In recent years, professional training technicians have found in this model an ideal means to create online professional communities, where they share knowledge, learn, and develop professionally, favoring the development of their respective professional areas and allowing participants to improve their professional identity that expands and revalues in the new global space thanks to its contributions to the community. It is relevant to observe how these new dynamics are transforming the ways of learning, working, and producing of many professionals; however, they are not being sufficiently explored in the training of VET students. Consequently, we need to advance in the understanding of pedagogical models that promote dynamics where students participate in online communities of practice and share knowledge openly. At the same time, we must investigate what implications these pedagogies have in the construction of students' pre-professional identity, academic achievements, and their social commitment.

\subsection{Professional Identity}

Identity refers to the meaning we attribute to ourselves through the lens of ourselves and others. It is a complex phenomenon, as one can have multiple identities, including personal identity, social identity, and work identity [11-13].

Professional identity relates to how an individual defines himself or herself in his professional life. This identity develops throughout life continuously through the dynamic integration of professional norms, values, and behaviors that are intertwined with one's own personal identity $[14,15]$.

VET students can begin to build their professional identity from the beginning of their training. In this case, we would speak of a pre-professional identity (PPI) that would act as a precursor to his or her future professional personality. On the process of construction of the pre-professional identity in students, some authors affirm that: 
Labor socialization, by imposing practices, habitual modes of action and a shared language, configures specific features of said identity. However, it begins to be built during the academic training process. Progressively, a change of subjective position is generated: the transition from the status of "student" to that of "professional" [16] (p. 68).

IPP encompasses awareness of and connection to the skills, qualities, behaviors, values, and standards of a student's chosen profession, as well as understanding of the professional self in relation to the larger general self $[11,17]$. According to researchers who are experts in the complex processes of development of PPI among students and future professionals, contextual, social and personal circumstances must be taken into account $[18,19]$, to which affective elements must be added [20].

On the other hand, although it is evident, it should be noted that the development of the PPI can only be carried out in relation to others, that is, in a community of practice. Communities of practice are groups of people who share a concern or passion for something they do and learn to do it better as they interact regularly. In these people, three characteristics usually converge: a domain of common interest; a community in which members help and learn from each other, and shared resources and practices [21]. The participation of students in these communities supports the formation of their PPI and contributes to the development of useful skills for their future work [17]. However, this only occurs when practical knowledge and reflective learning are articulated, as various studies have shown, practice and reflection are closely linked to professional development [22-24].

To promote the professional identity of students, they must be recognized in relation to the role they will play in the world of work when they finish their studies. This is more complicated if we consider that they have not yet entered the real world of work, where they will truly develop their professional identity, their "socio-professional identity" [25] (pp. 1-2) or their "work culture" [26] (p. 2). Terranova, López and Cabrera state:

Pre-professional practice is a training process of knowledge, skills, and values of permanent transformation. This is based on the reflection of the subjects as a way that guides his/her practical action. To do this, the student face a set of complex situations, which mean new challenges to assess the importance of his/her future profession. The pre-professional practice is a starting point in the professional career of each student, a space in which experience is acquired, on the role to play and the skills to solve situations typical of the profession [27] (p. 274).

In Spain, all vocational training students have to carry out a training stay in a workplace. This stay, except in Dual Vocational Training which is a specific program [28], takes place at the end of the last academic year of training [29], when the student has passed most of the subjects in the training plan; meanwhile, it is disconnected from communities of practice where the students could develop their PPI.

In general, in VET studies, training focuses on the development of knowledge and technical skills; the latter are achieved through laboratory practices and projects. In this way, as in other teachings, it contributes to building an identity as a student, but it does not address the development of professional identity [17]. However, the construction of identity as a student can also include the professional one, both developing in parallel. Ideally, within their responsibility to train for employability, students should also be agents in the development of their PPI as they advance in their training [30,31].

Although, traditionally, professional identity has been built through work and in interconnection with local networks of professionals; today, it is also promoted through online professional communities. In them, participants provide technical solutions and products from their field of knowledge, create global networks, and expand their professional identity through their contributions to the online community. This new dynamic opens up an excellent opportunity for students to participate in a community of professional practice without leaving the school. 
In addition, the digital professional identity is a source of recognition among professionals in the sector, and a way to obtain better jobs. In fact, part of the Curriculum Vitae can be reflected on the Internet and many employers track the digital footprint of the candidates, therefore, it can be a factor to improve employability. Consequently, vocational teachers are challenged to introduce pedagogical models consistent with these new ways of developing professional identities through online communities of practice. In this sense, open pedagogy can be a simple and powerful way to achieve it.

\subsection{Open Pedagogy}

The term "open pedagogy" is associated with Open Educational Resources (OER). As defined by UNESCO “Open Educational Resources (OER) are teaching, learning and research materials in any medium - digital or otherwise- that reside in the public domain or have been released under an open license that permits no-cost access, use, adaptation and redistribution by others with no or limited restrictions" [32] (p. 1).

According to Wickline "The idea behind Open Educational Resources (OER) is simple but powerful-educational materials made freely and legally available on the Internet for anyone to reuse, revise, remix and redistribute" [33] (p. 1). In fact, the "open" in the term OER (Open Educational Resources) indicates that these materials are licensed with copyright licenses that provide permission for everyone to participate in the $5 \mathrm{R}$ activities - retain, reuse, revise, remix, and redistribute [34].

- Retain-make, own, and control a copy of the resource (e.g., download and keep your own copy);

- Revise-edit, adapt, and modify your copy of the resource (e.g., translate into another language);

- Remix - combine your original or revised copy of the resource with other existing material to create something new (e.g., make a mashup);

- Reuse-use your original, revised, or remixed copy of the resource publicly (e.g., on a website, in a presentation, in a class);

- Redistribute-share copies of your original, revised, or remixed copy of the resource with others (e.g., post a copy online or give one to a friend) [34] (p. 1).

OERs are democratizing learning and transforming teaching, because these digital materials give many more people around the world access to free quality education. Knowledge ceases to have a cost and is available to all economies. Consequently, OERs have the potential to advance careers and economic development in low-income communities. In any case, to promote this movement, OER must leave the periphery and take center stage [33]. This implies the development of an open pedagogy, since the open licenses used in open educational resources allow teaching and learning techniques that are not possible with traditional copyrights.

In general, open pedagogy was defined in the context of open license possibilities [35]. Open pedagogy is an instructional method that decentralizes power dynamics in the classroom, engages students, and gives greater meaning to the work they do. Wiley [36] emphasized the link between OER and open pedagogy, "OER-enabled pedagogy" is defined as the set of teaching and learning practices that are only possible or practical in the context of the 5R permits that are characteristic of OER [37].

Wiley [36] distinguishes "renewable assignments" from "disposable assignments". Disposable assignments are those assignments that both faculty and students understand will ultimately be thrown away.

They're assignments that add no value to the world—after a student spends three hours creating it, a teacher spends 30 min grading it, and then the student throws it away (p. 1).

Disposable assignments are useful to improve a student's learning, but nothing else. Wiley calls our attention to the fact that millions of hours of work are done, graded, and thrown away each year. To overcome this limitation, Wiley introduces the idea of renewable 
assignments. These are assignments which both support an individual student's learning and result in new or improved open educational resources that provide a lasting benefit to the broader community of learners. This is a model that combines constructionism [38] and openness into OER-enabled pedagogy [36].

Under this vision, open pedagogy is not only about the teachers using OER in their classes, but also about the students getting involved in the creation of OER. This approach connects with the philosophy behind the taxonomy proposed by Bloom, who in the 1950s developed a hierarchy of cognitive processes for teaching and proposed that the creation of new knowledge had to start from remembering facts [39]. This taxonomy has been updated for the digital world [40] and maintains a great pedagogical consensus. The idea is for the student to focus their learning activity on activities that require higher order thinking strategies such as analyzing, evaluating, and creating. In this sense, OER-enabled pedagogy would be a privileged promoter for the development of these thinking strategies.

There is research that "indicate that students experienced various forms of extrinsic motivation during the project based on open pedagogy" [41] (p. 1). However, a recent cross-cultural systematic review, based on " 51 OER studies conducted in countries across the five continents [ ... ] found there is no significant difference in learning outcomes when instructors incorporate OER; and implementation of OER as instructional strategies is challenging but can be effective in supporting positive learning outcomes when properly designed" [42] (p.1). However, as Wiley says:

Increasing access to core instructional materials will necessarily make significant improvements in learning outcomes for students who otherwise wouldn't have had access to the materials (e.g., couldn't afford to purchase their textbooks). If the percentage of those students in a given population is large enough, their improvement in learning may even be detectable when comparing learning in the population before OER adoption with learning in the population after OER adoption. Saving significant amounts of money and doing no harm to learning outcomes (or even slightly improving learning outcomes) is clearly a win. However, there are much bigger victories to be won with openness [37] (p. 1).

In addition, recent research points to a lack of knowledge among students and teachers about OER, but when participating in open pedagogy experiences, participants indicate they are very satisfied with the concept of renewable assignments and are interested in sharing their work openly with credit and value helping others [43-45].

Until now, in vocational training, the impact of introducing a methodology based on open pedagogy on PPI has not been studied, and there is not enough literature on the effect on technical learning and the development of the commons of the professional area. Consequently, in this research we ask:

- Can a training model based on OER-enabled pedagogy promote the development of the PPI of VET students from the beginning of training?

- Does this model have effects on academic achievement?

- Does it have social implications?

These questions led us to set the following objectives:

1. Design a didactic strategy based on an OER-enabled pedagogy model to apply in professional training subjects during a full academic year.

2. Analyze the impact of this activity on their academic outcomes.

3. Analyze the impact of the initiative on the pre-professional identity of students through the perceptions of students and teachers.

4. Analyze the impact on the professional commons.

\section{Materials and Methods}

This research uses the anthropological perspective to investigate the impact of a training program based on an open pedagogy model, concretely, an OER-enabled pedagogy 
model: we evaluate the effect on pre-professional identity, the academic results of VET students, and the development of the commons of their professional field.

Methodologically, we have combined the bibliographic review with the empirical, quantitative, and qualitative data, collected in the ethnographic fieldwork that was carried out in a vocational training center located in the Community of Valencia (Spain). The economy of the region is based on agriculture and a residential tourism sector that has been gaining in importance, attracting people from other areas of Spain and from various European countries. Both agriculture and the tourism development model have required abundant low-skilled labor, so growth boosted by both economic sectors has fostered a significant migration of families mainly from North Africa, South America, and Europe. Due to these migratory flows, the municipality has a high multiculturality, and of its approximately 22,000 inhabitants, almost $40 \%$ of the population is of foreign origin, according to data from the National Institute of Statistics referring to 2018.

We have used a mixed methods approach to carry out this research in the educational field, because as other authors have shown, "The use of mixed method designs are, day by day, an excellent alternative to address research issues in the field educational" [46] (p. 15).

Thus, we have applied a mixed methods design in this research, using both qualitative and quantitative techniques, since our research experience has shown us that this is the best methodological option to triangulate the theory with the information obtained, for example, with interviews, surveys, and participant observation. In addition, and as advocated by various authors [47-49], using more than one method and different types of techniques gives the possibility of understanding more in depth, and accurately, the complexity of human behaviors and learning processes, such as the one we have studied.

The research was carried out on 77 students enrolled in a VET course called "Microcomputer Systems and Networks", during the 2017-2018 and 2018-2019 academic years. The studies of "Microcomputer Systems and Networks" have a duration of two academic years and consist of thirteen subjects, ten of a professional nature, two of technical English, and a subject of training in work centers as reflected in Table 1.

Table 1. Subjects of the title "Microcomputer Networks and Systems".

\begin{tabular}{cc}
\hline 1st Academic Year & 2nd Academic Year \\
\hline Assembly and Maintenance of Computers & Network Operating Systems \\
\hline Local Networks & Computer Safety \\
\hline Office Automation Applications & Network Services \\
\hline Single-user Operating Systems & Web Applications \\
\hline Professional Training and Guidance & Business and Entrepreneurial Initiative \\
\hline Technical English I & Technical English II \\
\hline
\end{tabular}

Source: Department of Education (Community of Valencia) [50].

In agreement with the head of the department and, taking advantage of the collaboration of the teaching staff, it was agreed to carry out the experience in two professional subjects, specifically in the subject of "Local Networks", which is taught in the first year, and in the subject of "Computer Safety" which is taught in the second year.

During the 2017-2018 academic year, there were 38 students enrolled (22 in the first year and 16 in the second year). In the 2018-2019 academic year there were 39 students (22 students enrolled in the first year and 17 in the second). Male students who finished Secondary Education the previous year are mainly interested in this training. As can be seen in Table 2, in the 2017-2018 academic year, there were only two female students and 36 male students, and in 2018-2019, one female student and 38 male students. This overrepresentation of male students follows the observable trend in the training of professionals in all areas related to STEM (Science, Technology, Engineering, and Mathematics) studies. 
According to the Observatory of Vocational Training in Spain, in the 2020 annual report, only $11 \%$ of people enrolled in STEM Vocational Training studies are women [51]. This is consistent with various studies carried out with a gender perspective [52,53], where the factors that influence the gender gap in STEM studies and the low female participation were analyzed, determining that it is due to the maintenance of the hegemonic ideological representations of gender and work.

Table 2. Student body distribution by subject and course for each academic year.

\begin{tabular}{ccccccc}
\hline & \multicolumn{3}{c}{ Local Networks (1st Year) } & \multicolumn{2}{c}{ Computer Safety (2nd Year) } \\
\hline & Men & Women & Age average & Men & Women & Age average \\
\hline $2017-2018$ & 20 & 2 & 18.4 & 16 & 0 & 19.6 \\
\hline $2018-2019$ & 21 & 1 & 18.3 & 17 & 0 & 19.7 \\
\hline
\end{tabular}

Source: Own elaboration based on enrollment data.

The age of the students was between 18 and 23 years old. Table 2 shows the distribution by average age and sex of the students in each subject and academic year.

Regarding the origin of the student body, the largest number is made up of those of Spanish origin, followed by immigrant students of Ecuadorian and Moroccan origin. Specifically, during the 2017-2018 academic year, in the first course, 17 were Spaniards and 5 Ecuadorians, and in the second course, 14 were Spaniards and 2 Ecuadorians. In the 2018-2019 academic year, there were 18 Spaniards, 3 Ecuadorians, and 1 Moroccan, and in the second course, 13 were Spanish and 4 Ecuadorians.

The investigation was carried out in two phases. The first phase, during the academic year 2017-2018, we collected information on the teaching methodology, learning results and perceptions of the students about their competence and professional identity, and other aspects of their training tasks.

In the second phase, carried out during the 2018-2019 academic year, we designed an educational intervention based on an OER-enabled pedagogy to use the products derived from the training of students beyond the mere activity of teaching and evaluation. The teachers of the respective subjects carried out the intervention following their traditional methods but enriched by the principles of open pedagogy. Specifically, each student was asked not to hand over their work to the teacher, but to publish them in an open virtual space decided by themselves, for example, blog, website, YouTube channel, or other social networks. In addition, each time the works were published, the teachers encouraged them to analyze their classmates' works and give feedback to them through online comments; if they considered some of them relevant, they could link and distribute them through their own channels. This dynamic made it possible to generate a community of professional practice with the entire group of students and was also open to other agents outside the center. Since all the students were of legal age, they were allowed to create their public profiles both with a pseudonym or with their real identity.

The student population for each academic year is similar and they were subjected to the same training content and the same teaching staff. For both academic years, the same number of tasks was planned and with the same disciplinary objectives, specifically, 20 jobs were scheduled in Local Networks and 16 in Computer Security. The teachers applied their traditional methodology based on Project-Based Learning, through working groups, specifically, 7 working groups on Local Networks and 6 working groups on Computer Safety. The fundamental difference was the innovation variant indicated for the students of the 2018-2019 academic year.

The data collection was carried out through three instruments: the evaluation sheets applied by each teacher to determine the level of achievement of each project (Table 3), the Likert-type surveys that were passed to the students at the end of each course (Table 4), and open interviews with teachers and the management team. Both the work evaluation files and the survey were agreed upon and validated with the professors involved and the head of the department. 
Table 3. Evaluation form for the students' work.

1. Process.

1.1. Apply the appropriate methodology in solving the problem/project.

1.2. Demonstrates attitudes typical of a technician: curiosity, interest, rigor, and precision.

1.3. It is systematic in the application of the work procedure.

1.4. Shows creativity in finding solutions to problems that arise.

2. Product.

2.1. The final product fully responds to the problem raised.

2.2. The project has been carried out in the proposed time.

3. Activity report or memory.

3.1. Express himself or herself correctly and use professional vocabulary and language.

3.2. Collect all the relevant elements to understand and reproduce the project.

4. Attitudes.

4.1. Shows effort and autonomy in personal work, with an active and responsible attitude in tasks.

4.2. Is motivated by homework.

4.3. Participate and collaborate with your colleagues in solving problems.

Note: range of values for each item: 1 -lowest rating, $\ldots, 5$-highest rating.

Source: Own elaboration.

Table 4. Survey for students.

1. Student's perception of their own level of competence and professional identity.

1.1. My general proficiency level is:

1.2. My level of competence to solve a technical problem is:

1.3. My level of competence to document the process and create a procedure or technical report is:

1.4. My level of competence on publishing content on blogs, websites, RRSS or other spaces on the Internet is:

1.5. My level of competence on Creative Commons licenses and copyrights is:

1.6. I feel competent to work as a technician.

2. Student's perception of the work documentation process.

2.1. I am motivated by the fact of documenting the work done.

2.2. Documenting how the problem is solved is very important.

23. It helps to have more confidence in my work.

2.4. Help improve my technical skills.

2.5. Helps improve my expression and communication skills.

3. Student's perception of the value of the projects carried out during the course.

3.1. I usually review the work of colleagues.

3.2. Knowing the work of colleagues helps me improve mine.

3.3. The work done may be useful to others.

Note: range of values for each item: 1 -lowest rating, . . , 5-highest rating. Source: Own elaboration.

In our research, we have attached great importance to the qualitative approach, since it has been essential to know through open interviews the opinion of the teaching team and the management team of the center on the educational experience analyzed. These opinions expressed in the open interviews were triangulated with the evaluation form that 
each teacher had prepared throughout the course and with the direct observation of the researchers of this project in the classroom.

These qualitative data were in turn triangulated with the data obtained in the surveys carried out with the students.

Researchers share the idea of authors who defend that an essential task of the social researcher who seeks to understand complex social facts, as the case we analyze in this research, requires the analysis of the experiential experience of the subjects who live it, in our case, the teachers and the teaching team, as it is a way of " (.. ) understanding their various social constructions on the meaning of facts and knowledge" [54] (p. 8).

Regarding the interviews carried out with the teaching staff and the management team, we resorted to indexing by categories of analysis of the contents obtained; in this way, through the identification of words and recurring main ideas, we established an interpretive categorization. We identified trends, contradictions, reiterations, and absences that allowed us to conceptualize, which we were later able to validate with triangulation.

Data analysis was supported with procedures such as contrasting data obtained in surveys, interviews, documentary sources, and direct observation. We triangulated the results of the most descriptive method with the most phenomenological-interpretive, giving a voice to the informants of our study.

\section{Results and Discussion}

In the first year of fieldwork, we observed that the teachers followed a Project-Based Learning methodology, and the students generated real products or solutions to technical problems, giving the teacher the product or the resolution procedure of the problem. A multitude of extremely interesting works were developed by the students throughout the course. This production of materials did not leave the school, being discarded once evaluated. The second academic year, with the introduction of the OER-enabled pedagogy model, students published their work, commented on the work of others, and received feedback from colleagues and external agents, generating an open and dynamic community of practice. In the following sections, we analyze the effect of this methodological change on academic outcomes, and on the students' perception of their competence and professional identity, on the change in the appreciation of the value of the documentation process and on the usefulness of the work made.

\subsection{Effect on Academic Performance}

Local Networks and Computer Safety courses have a specific training program. However, in both subjects, in the two academic years that the research was carried out, the students received training on open licenses, Creative Commons licenses, digital identity, and advantages and risks of creating a digital identity, specifically, in Local Networks. This training lasted $5 \mathrm{~h}$ and in computer security, $2 \mathrm{~h}$.

In Table 5, we summarize the academic results of the students in the subject of Local Networks before and after the educational intervention based on OER-enabled pedagogy. The table shows the averages of all the evaluations, and we added the standard deviation $(\sigma)$ of the values to visualize the degree of dispersion. To understand the values, it must be taken into account that the range of responses is between 1 and 5 , therefore, the middle value of the range is 3 . Next, for each item analyzed, we show the increase in the average $(\Delta)$, that is, the difference between the average of the second year and the first year. Finally, we add a column with the percentage of variation between the means of both academic years for each item analyzed. The Percentage of Variation of the Average (PVA) results from the difference of the first value minus the second divided by the first value, and multiplied by 100; this statistic gives us a vision of the degree of variation of the analyzed phenomenon. We have considered that there is a very significant change when the variation is greater than $20 \%$, significant change for variations between $10 \%$ and $20 \%$, little significant change for variations between $5 \%$ and $10 \%$, and not significant for variations less than $5 \%$. 
Table 5. Results of the evaluation of the works for the subject of Local Networks.

\begin{tabular}{|c|c|c|c|c|c|c|}
\hline & 2017-2018 & $\sigma$ & 2018-2019 & $\sigma$ & $\Delta$ & PVA \\
\hline \multicolumn{7}{|l|}{ 1. Process. } \\
\hline 1.1. Apply the appropriate methodology in solving the problem/project. & 4.22 & 0.92 & 4.16 & 0.85 & -0.06 & $-1.36 \%$ \\
\hline 1.2. Demonstrates attitudes typical of a technician: curiosity, interest, rigor and precision. & 3.24 & 0.97 & 3.11 & 0.64 & -0.14 & $-4.16 \%$ \\
\hline 1.3. Is systematic in the application of the work procedure. & 3.24 & 0.97 & 3.10 & 1.03 & -0.15 & $-4.52 \%$ \\
\hline 1.4. Shows creativity in finding solutions to problems that arise. & 3.37 & 0.98 & 4.79 & 0.56 & 1.42 & $42.27 \%$ \\
\hline \multicolumn{7}{|l|}{ 2. Product. } \\
\hline 2.1. The final product fully responds to the problem posed. & 4.38 & 0.78 & 4.46 & 0.59 & 0.08 & $1.75 \%$ \\
\hline 2.2. The project has been completed in the planned time. & 4.86 & 0.34 & 4.60 & 0.70 & -0.26 & $-5.31 \%$ \\
\hline \multicolumn{7}{|l|}{ 3. Working paper. } \\
\hline 3.1. Expresses correctly and uses professional vocabulary and language. & 3.45 & 0.97 & 4.46 & 0.59 & 1.01 & $29.29 \%$ \\
\hline 3.2. Collects all the relevant elements to understand and reproduce the project. & 3.40 & 1.02 & 4.33 & 0.65 & 0.93 & $27.25 \%$ \\
\hline \multicolumn{7}{|l|}{ 4. Attitudes. } \\
\hline $\begin{array}{l}\text { 4.1. Shows effort and autonomy in personal work, with an active and responsible attitude } \\
\text { in the tasks. }\end{array}$ & 3.13 & 1.08 & 3.00 & 0.55 & -0.13 & $-4.07 \%$ \\
\hline 4.2. Is motivated by work. & 2.90 & 0.28 & 3.37 & 0.98 & 0.47 & $16.12 \%$ \\
\hline 4.3. Participates and collaborates with their colleagues in solving problems. & 4.25 & 0.62 & 4.33 & 0.65 & 0.08 & $1.88 \%$ \\
\hline
\end{tabular}

Source: Own elaboration.

Analyzing Table 5, a very significant improvement (PVA greater than 20\%) is observed in the items "Shows creativity in the search for solutions to problems that arise", "Expresses correctly and uses professional vocabulary and language" and "Collect all the relevant elements to understand and reproduce the project". The item "Is motivated by work" is also significant (PVA between 10\% and 20\%). There are no very significant or significant negative changes, except for a minor negative effect on the indicator "The project has been completed in the expected time", which indicates that the delivery time of some works was slightly delayed.

The information collected in the table shows us that with the educational intervention, there was a very significant improvement in the item "Collect all the relevant elements to understand and reproduce the project" and very closely followed by the item "Expresses correctly and uses professional vocabulary and language"; the item "Is motivated by work" also improves with a significant change. The rest of the values have little or no significant variations. It should be noted that in the second year, they have only promoted $72 \%$ of the students enrolled in the first year (16 of 22, in the academic year 2017-2018) and 77\% (17 of 22, in the academic year 2018-2019), therefore, the second-year students have a higher average of skills, in addition to one more year of professional training, consequently, the PVA is notably lower, that is, there is less scope for improvement than in the first year.

In summary, both subjects significantly or very significantly improved the items related to the working paper of the works performed. In addition, there is a lot of concentration in the results of the evaluation of each student, since $\sigma$ in general is quite low for all the items analyzed.

Similarly, in Table 6, we show the results for the second-year subject of "Computer Safety". 
Table 6. Analysis of the results of the evaluation of the works for the subject of Computer Safety.

\begin{tabular}{|c|c|c|c|c|c|c|}
\hline & 2017-2018 & $\sigma$ & 2018-2019 & $\sigma$ & $\Delta$ & PVA \\
\hline \multicolumn{7}{|l|}{ 1. Process. } \\
\hline 1.1. Apply the appropriate methodology in solving the problem/project. & 4.85 & 0.45 & 4.86 & 0.34 & 0.01 & $0.27 \%$ \\
\hline $\begin{array}{l}\text { 1.2. Demonstrates attitudes typical of a technician: curiosity, interest, rigor, } \\
\text { and precision. }\end{array}$ & 4.16 & 0.85 & 4.25 & 0.62 & 0.08 & $2.03 \%$ \\
\hline 1.3. Is systematic in the application of the work procedure. & 4.52 & 0.72 & 4.77 & 0.41 & 0.25 & $5.61 \%$ \\
\hline 1.4. Shows creativity in finding solutions to problems that arise. & 4.02 & 0.90 & 4.3 & 0.8 & 0.29 & $7.12 \%$ \\
\hline \multicolumn{7}{|l|}{ 2. Product. } \\
\hline 2.1. The final product fully responds to the problem posed. & 4.85 & 0.45 & 4.86 & 0.34 & 0.01 & $0.27 \%$ \\
\hline 2.2. The project has been completed in the planned time & 4.77 & 0.41 & 4.85 & 0.45 & 0.08 & $1.60 \%$ \\
\hline \multicolumn{7}{|l|}{ 3. Working paper. } \\
\hline 3.1. Expresses correctly and uses professional vocabulary and language. & 3.69 & 1.01 & 4.42 & 0.59 & 0.73 & $19.85 \%$ \\
\hline $\begin{array}{l}\text { 3.2. Collect all the relevant elements to understand and reproduce the } \\
\text { project. }\end{array}$ & 3.72 & 1.03 & 4.55 & 0.77 & 0.80 & $21.46 \%$ \\
\hline \multicolumn{7}{|l|}{ 4. Attitudes. } \\
\hline $\begin{array}{l}\text { 4.1. Shows effort and autonomy in personal work, with an active and } \\
\text { responsible attitude in the tasks. }\end{array}$ & 4.46 & 0.59 & 4.33 & 0.65 & -0.13 & $-3.01 \%$ \\
\hline 4.2. Is motivated by work. & 4.07 & 0.87 & 4.60 & 0.70 & 0.53 & $13.01 \%$ \\
\hline 4.3. Participates and collaborates with their colleagues in solving problems. & 4.85 & 0.45 & 4.72 & 0.53 & -0.13 & $-2.75 \%$ \\
\hline
\end{tabular}

Source: Own elaboration.

We contrast these data with the information obtained from the interviews with the teachers. They confirmed that the use of the proposed methodology resulted in a substantial improvement in the quality of the working papers; in addition, the students turned to the use of video as a publication format.

I have had many works delivered in video format with excellent quality, it has really surprised me. (Computer Safety teacher).

From the beginning they were motivated by the idea of publishing their work on the Web, and being able to choose to produce their reports in formats that were not written documents. (Local Networks teacher).

The most difficult thing is deciding if you make a YouTube channel, a blog, a website or if you use Twitter. I started with a blog, but now I have a website and a YouTube channel. And sometimes I post some on my Instagram to amaze my friends [smiles]. (Local Networks student, academic year 2018-2019, this idea was referenced by 10 of the 21 students in this course).

Although the student receives training on publishing and licensing, they did not take any specific course on video management. However, most of the working papers, $66 \%$, were delivered in this format and the rest in hypertext documents, enriched with images and links. The students avoid doing the reports of their projects in textual formats, preferring the most common means of expression in cyberculture, such as video.

For me it is more fun to make a video to explain the process of solving a practice than to write a report. (Computer Safety student, academic year 2018-2019, this idea was shared by all students in the course).

Some works need a written report, but others are easier to do a short video explaining the process. It depends on the problem so you choose, for example, this work [points to the screen] in video is very fast to document, but others are easier to document in writing. (Computer Safety student, academic year 2018-2019, this idea was shared by all students in the course). 
To explain short work procedures, it may be quicker to take a few screenshots and explain them than to record and lay out a video. So it all depends on the work and what is faster. (Local Networks student, academic year 2018-2019, this idea was referenced by 8 of the 21 students in this course).

On the other hand, the possibility of seeing the work of their classmates published and comparing it with their own generated a dynamic of reviews and positive improvement according to the teaching staff.

It has also been positive that they have easy access to the work of their colleagues, because when they see how others solve a problem, they learn other solutions and improve their own. (Local Networks professor).

In addition, teachers encourage them to comment on the work of others, so that a true community of practice is produced.

What is most difficult for them is to give feedback to their classmates, they do not feel safe, but little by little they are doing it. I indicate to them that I will highly value these interventions in the final grade. (Computer Safety professor).

In turn, the student gains perspective on the work done throughout the course, since these publications are a portfolio of everything done, something that lasts over time. Whereas, the works that were only submitted and corrected, without publishing them, are sometimes not remembered, and sometimes not preserved. This fact was empirically verified. At the end of each course, we asked the students to think for a few minutes about the number of works they had done and write it down, then they were asked to check that number by checking their notes, storage devices, etc., and recalculate the number of works performed. The students of the 2017-2018 academic year forgot an average of 12 out of 36 $(33.3 \%)$, and once their work files were reviewed, they still left out an average of 4 out of 36 $(11.1 \%)$. The students of the 2018-2019 academic year remembered $90 \%$ of the works in the first instance and after reviewing their publications, $100 \%$. Clearly, the students who published their work are more aware of the tasks performed.

I don't remember half of them. I have done a mental "reset". (Local Networks student, during the process of listing the work done, 2017-2018).

I put the ones I remembered, because I lost the pen drive with all the works. (Local Networks student, 2017-2018 academic year).

In summary, the students improved the quality of the documentation of the works, and even the attitude that, although it already had a high level, improved slightly. They worked on their digital competence, developing multimedia products, such as video tutorials, and also improve a little more in the high attitudinal levels that the student already presented with respect to the motivation for the task and the collaboration with their classmates. However, there is no significant improvement in technical achievements; the revised items that have to do with the resolution process and with the final product that the student has to develop, did not change substantially. These data coincide with the systematic review carried out by Luo et al. [42], who claims that there is no significant difference in learning outcomes when instructors incorporate OER, and implementation of OER as instructional strategies is challenging but can be effective in supporting positive learning outcomes when properly designed.

\subsection{Students' Perception of the Pre-Professional Identity, the Documentation Process, and the Usefulness of the Work Carried Out}

To address the effect of the methodological change on the PPI, we applied the designed survey (Table 4) in both academic years. This survey allowed us to find out the perception of students regarding their competence and professional identity, about the documentation process and the value of the work developed, and compare it for each course and subject. The survey was passed at the end of the academic year. Local Networks students were finishing their first year of training, and Computer Safety students, being a last-year subject, 
when they completed the survey, were finishing their training and about to graduate as "Microcomputer Systems and Networks" Technicians.

Each of the summary tables (Tables 7-12) show the average values for each course and the percentage of variation of the average (PVA).

Table 7. Students' perception of their own level of competence and professional identity. Local Networks students' final survey.

\begin{tabular}{|c|c|c|c|}
\hline & 2017-2018 & 2018-2019 & PVA \\
\hline 1.1. My general professional competence level is: & 2.80 & 3.1 & $10.56 \%$ \\
\hline $\begin{array}{l}\text { 1.2. My level of proficiency in solving a technical } \\
\text { problem is: }\end{array}$ & 3.37 & 4.07 & $20.97 \%$ \\
\hline $\begin{array}{l}\text { 1.3. My level of competence to document the } \\
\text { process and create a procedure or working paper } \\
\text { of this is: }\end{array}$ & 3.71 & 4.15 & $11.82 \%$ \\
\hline $\begin{array}{l}\text { 1.4. My level of competence to publish on blogs, } \\
\text { websites, social networks or other spaces on the } \\
\text { Internet is: }\end{array}$ & 3.67 & 4.75 & $29.35 \%$ \\
\hline $\begin{array}{l}\text { 1.5. My level of competence on Creative Commons } \\
\text { licenses and copyrights is: }\end{array}$ & 2.21 & 4.80 & $117.40 \%$ \\
\hline $\begin{array}{l}\text { 1.6. I feel competent to work as a technician in a } \\
\text { company of the sector: }\end{array}$ & 2.21 & 2.65 & $19.91 \%$ \\
\hline
\end{tabular}

Source: Own elaboration.

Table 8. Students' perception of their own level of competence and professional identity. Computer Safety students' final survey.

\begin{tabular}{|c|c|c|c|}
\hline & 2017-2018 & 2018-2019 & PVA \\
\hline 1.1. My general professional competence level is: & 4.4 & 4.6 & $4.55 \%$ \\
\hline $\begin{array}{l}\text { 1.2. My level of proficiency in solving a technical } \\
\text { problem is: }\end{array}$ & 4.21 & 4.91 & $16.58 \%$ \\
\hline $\begin{array}{l}\text { 1.3. My level of competence to document the } \\
\text { process and create a procedure or working paper } \\
\text { of this is: }\end{array}$ & 3.81 & 4.57 & $20.05 \%$ \\
\hline $\begin{array}{l}\text { 1.4. My level of competence to publish on blogs, } \\
\text { websites, social networks or other spaces on the } \\
\text { Internet is: }\end{array}$ & 3.67 & 3.95 & $7.51 \%$ \\
\hline $\begin{array}{l}\text { 1.5. My level of competence on Creative Commons } \\
\text { licenses and copyrights is: }\end{array}$ & 2.49 & 4.95 & $98.71 \%$ \\
\hline $\begin{array}{l}\text { 1.6. I feel competent to work as a technician in a } \\
\text { company of the sector: }\end{array}$ & 4.1 & 4.72 & $15.02 \%$ \\
\hline
\end{tabular}


Table 9. Perception about the documentation process. Final Local Networks students' survey.

\begin{tabular}{lccc}
\hline & 2017-2018 & 2018-2019 & PVA \\
\hline $\begin{array}{l}\text { 2.1. I am motivated by the fact of } \\
\text { documenting the work done: }\end{array}$ & 1.3 & 3.45 & $165.35 \%$ \\
\hline $\begin{array}{l}\text { 2.2. Documenting how the problem is } \\
\text { solved is very important: }\end{array}$ & 2.54 & 3.21 & $26.38 \%$ \\
\hline $\begin{array}{l}\text { 2.3. It helps to have more confidence in my } \\
\text { work: }\end{array}$ & 2.67 & 3.4 & $27.34 \%$ \\
\hline $\begin{array}{l}\text { 2.4. Helps to improve my technical skills: } \\
\begin{array}{l}\text { 2.5. Helps improve my expression and } \\
\text { communication skills: }\end{array}\end{array}$ & 1.6 & 3.54 & $121.25 \%$ \\
\hline
\end{tabular}

Source: Own elaboration.

Table 10. Perception about the documentation process. Computer Safety students' final survey.

\begin{tabular}{lccc}
\hline & 2017-2018 & 2018-2019 & PVA \\
\hline $\begin{array}{l}\text { 2.1. I am motivated by the fact of documenting the } \\
\text { work done: }\end{array}$ & 1.67 & 3.54 & $111.98 \%$ \\
\hline $\begin{array}{l}\text { 2.2. Documenting how the problem is solved is } \\
\text { very important: }\end{array}$ & 2.76 & 3.67 & $32.97 \%$ \\
\hline $\begin{array}{l}\text { 2.3. It helps to have more confidence in my work: } \\
\text { 2.4. Helps to improve my technical skills: }\end{array}$ & 2.84 & 3.54 & $24.81 \%$ \\
\hline $\begin{array}{l}\text { 2.5. Helps to improve my expression and } \\
\text { communication skills: }\end{array}$ & 3.41 & 3.65 & $93.12 \%$ \\
\hline $\begin{array}{l}\text { Source: Own elaboration. } \\
\text { n }\end{array}$ & & & $32.08 \%$ \\
\hline
\end{tabular}

Source: Own elaboration.

Table 11. Perception of the value of the projects carried out. Final Local Networks students' survey.

\begin{tabular}{lccc}
\hline & 2017-2018 & 2018-2019 & PVA \\
\hline 3.1. I usually review the work of colleagues: & 2.21 & 4.67 & $111.42 \%$ \\
\hline $\begin{array}{l}\text { 3.2. Knowing the work of colleagues helps } \\
\text { me improve mine: }\end{array}$ & 3.40 & 4.72 & $38.73 \%$ \\
\hline 3.3. The work done may be useful to others: & 3.21 & 4.62 & $43.82 \%$ \\
\hline
\end{tabular}

Source: Own elaboration.

Table 12. Perception of the value of the projects carried out. Computer Safety students' final survey.

\begin{tabular}{lccc}
\hline & 2017-2018 & 2018-2019 & PVA \\
\hline 3.1. I usually review the work of colleagues: & 2.35 & 4.87 & $107.22 \%$ \\
\hline $\begin{array}{l}\text { 3.2. Knowing the work of colleagues helps } \\
\text { me improve mine: }\end{array}$ & 4.32 & 4.91 & $13.61 \%$ \\
\hline $\begin{array}{l}\text { 3.3. The work done may be useful to others: } \\
\text { Source: Own elaboration. }\end{array}$ & 3.56 & 4.89 & $37.36 \%$ \\
\hline
\end{tabular}

\subsubsection{Students' Perception of Their Own Level of Competence and Professional Identity}

Next, we are going to present the students' perception of their own level of competence and professional identity in these two academic years, 2017-2018 and 2018-2019, both of the students of the Local Networks subject (Table 7) and of the students of the Computer Safety subject (Table 8).

In the subject of Local Networks, the students improved all the indicators, especially their perception of the level of competence to solve a technical problem and the feeling of competence to work in a company in the professional sector; both aspects improved by $20 \%$. 
Very significant has been the perception of other aspects of their professional competence, such as the publication on the Internet that increased by almost $30 \%$ and the management of creative licenses and copyrights that improved by $117.4 \%$.

In the Computer Safety subject, all the indicators improve, highlighting the competence to handle Creative Commons licenses and copyrights, which improves by $98.71 \%$ since it was at quite low levels in the previous year. Other indicators such as the competence to solve technical problems, to document, and to work as a technician in companies in the sector improves between 15-20\%. It is an important change although somewhat less than in the Local Networks subject. The reason is that students in the second year-as is logical when they are about to graduate-present these items much higher than in the first year.

Teachers express satisfaction with the published work and acknowledge that there has been an improvement in skills related to licensing and online publishing.

Although we have had to insist, the students have assumed the need to put the correct licenses to their work. I think it is essential knowledge to be able to publish online. (Local Networks teacher).

We left them free to publish in the format they considered most appropriate depending on the type of project, many have chosen video. We have not given them any training in this regard, however, they have been able to create video tutorials with a professional quality. (Computer Safety teacher).

The students have shown interest from the beginning in this new model, although at the beginning, they had many doubts about how to publish.

When at the end of the course we see all the published works, you say: wow! I have done a lot of things! (Local Networks student, 2018-2019 academic year).

The students show more awareness of the value of what they publish and an improvement in their self-perception as technicians. This implies a boost in the development of the PPI. Therefore, as we have been able to verify in our research and in line with other studies, certain practices carried out with students positively influence the construction and reconstruction of their future professional identity [23,55].

\subsubsection{Student's Perception of the Documentation Process}

The proposed methodology fundamentally affects the delivery model of the development reports of their works, going from delivering them to the teacher and then forgetting them, to publishing them as OER. It is logical that there is a substantial change in the elements involved.

Thus, in Local Networks subject, as seen in Table 9, the increase in motivation to document is very significant. In the 2017-2018 academic year, it was very low, which implied a high rejection of the report format and delivery model; however, in the 2018-2019 academic year, it moved to an intermediate position with an increase of $165.35 \%$ in the valuation. Equally significant is the perception of the impact of documentation to improve technical skills, while in the 2017-2018 academic year, it received the lowest rating by going to an average rating, with an increase of $121.25 \%$. Less significant, although important, are the increases in the appreciation of the documentation process, with an improvement of $26.38 \%$, the influence on self-confidence, with an increase of $27.34 \%$, and the impact on expression and communication skills, with a $38.94 \%$ increase.

In the subject of Computer Safety (Table 10), the motivation to document increases by $111.98 \%$, the student improves the consideration of this task as a way to perfect their technical skills, with an increase of $93.12 \%$. These are two indicators that were very low with the previous methodology. Others that were higher such as the importance of documentation, confidence in their work, and improvement of expression and communication skills were also increased by around $30 \%$.

We can affirm, in accordance with the data and the opinion of the teachers, that there is constant resistance on the part of the students to document the work. The student would prefer to solve the technical problem and not generate any report on the process. However, 
the exercise of the profession and, therefore, the training requires that the student knows how to document work procedures and problem solving. In this sense, the methodology has been a positive stimulus to overcome this resistance.

All the courses we have the same struggle with the students. They do not understand the need to document the work, to do technical procedures, and explain how they have solved the problem. (Local Networks teacher).

Large companies follow rigorous protocols and document everything, so workers don't have to invent the wheel every time they perform a job or solve a problem. It is a question of efficiency, which the student has to assimilate. And allowing them to publish their work and use multimedia formats has made it easier for them. (Computer security professor).

\subsubsection{Perception of the Value of the Projects Carried Out}

In this section, we stop at the analysis of the perception that the students of the two subjects selected in these two years have of the value of the projects carried out (Tables 11 and 12).

Local Networks students doubled their interest in reviewing the work of their colleagues, with an increase of $111.42 \%$ compared to the previous year. This change, as indicated, implies a review of one's own practice when comparing it with the achievements of others, which has a positive impact on the improvement of the learning, as pointed out by the students themselves, by increasing their assessment by $38.73 \%$ of the indicator "Knowing the work of colleagues helps me improve mine". In addition, the awareness that published works can be useful to others improved, as indicated by the $43.82 \%$ increase in the item "Works carried out can be useful to others".

For second-year students, in Computer Safety subject (Table 12), their inclination to review the work of their classmates also doubles, with an increase of $107.22 \%$. Their perception that knowing the work of their colleagues improves theirs slightly increases-a value that was already very high, so there was little scope for improvement. However, the $37.36 \%$ increase in perception that the work they have done can be useful to others is very significant.

In addition, publishing their work is useful for students to show their learning.

When my father asks me what we do in class, I show him my blog. (Local Networks student, this idea was referenced by 15 of the 21 students in this course).

Some friends, thanks to seeing the work we publish, have decided to enroll for the next course. (Computer Safety student, 2018-2019 academic year, this idea was referenced by 4 of the 17 students in this course).

On the other hand, students have generated a large number of OERs that they have distributed through their own social networks and publication spaces, enriching the commons of resources on Computer Safety and Local Networks. Specifically, the seven working groups of the Local Networks subject created 140 OERs throughout the course and the six Computer Safety working groups generated 96 OERs. Students and teachers consider this material valuable, which can be used for other students, but also for the general population.

Some videos are useful for anyone. In Local Networks, students install operating systems and configure them to connect them to printers and other equipment. Anyone following the video tutorials could do all of this at home. (Local Networks teacher).

The other day, a friend asked me how to install a digital certificate, and I sent them a video tutorial from one of my students. (Computer Security Teacher).

All of us search the Internet for videos and tutorials to solve problems. All this material that students generate while training can help a lot of people. (Head of the Informatics and Communications Department). 
The educational center even selected some tutorial videos made by the students to publish them on its website and promote the work carried out in the classroom. The head of the department who has participated and closely followed all the change in methodology adds that this approach improves the visibility of what is done in the center and favors the enrollment of new students in these courses.

We have published some of the students' work on the website of the center to make what we do visible and thus encourage other students to carry out these studies. (Head of Informatics and Communications Department).

In short, with this methodological approach, knowledge leaves the classroom and the student participates in professional networks from the beginning of their training. The students' perception of their competence and professional identity increased in both courses, especially in the first year where it was lower. Therefore, this methodology has fostered a better self-concept of students as technicians from the beginning of their training. However, the most significant change has been in the perception of their competence to handle copyright and open licenses, as well as their motivation and appreciation of the documentation process. They also consider that their work can be useful to others, which denotes a greater commitment to the principles of free licenses and the open movement. Thus, practices such as those analyzed with the students that are the object of our study "facilitate the reflection of the students themselves and the awareness of their educational progress, aspects that directly affect the acquisition and reinforcement of their professional identity from three dimensions: self-image, the social mission and the ethical commitment to the profession" [56] (p. 42).

\section{Conclusions}

Although there is growing research on OER, it is very limited on the conformation of the PPI of VET students, and we are not aware of any research that has addressed the effect of the use of OER-enabled pedagogy on the PPI and the commons. Therefore, with this ethnography, we make a new contribution to pedagogical and scientific knowledge on the subject.

As a summary of what is stated in the Results and Discussion section, we would like to highlight the most relevant findings of the research objectives of this work. Objective one consisted of designing, in collaboration with the teachers of the educational center, a pedagogical model based on OER that was followed during an academic year, thanks to this collaboration and the commitment of the teachers, together with the fieldwork of the research team; we have been able to answer the research questions and achieve the rest of the proposed objectives.

Specifically, in objective number two, we set out to analyze the impact of this activity on their academic outcomes, concluding that the methodology based on OER-enabled pedagogy has facilitated a significant improvement in various aspects of the student's work. Students, who have always shown resistance to document their works, are more motivated by the documentation process. There has been a change in the role of the student who acquires greater initiative and leadership in the teaching-learning process. The online publication and the construction of a community of practice allows constant feedback between the classmates and the teachers, with benefits in the continuous evaluation of learning.

In objective number three, we focused on analyzing the impact of the initiative on the pre-professional identity of students through the perceptions of students and teachers, concluding that, although there is no improvement in specifically technical learning, selfperception as vocational training technicians has improved from the first year, which implies a boost in the development of their pre-professional identity.

In addition, there has been a greater understanding and commitment to the principles underlying the OER movement and the value of the professional commons, and most importantly, a large number of useful OERs have been contributed to the commons. This fact responds to the fourth research objective. 
Finally, regarding objective four, which focused on analyzing the impact on the professional commons, we observed that the student reached a greater understanding and commitment to the principles underlying the OER movement and the value of the professional commons and, furthermore, through this experience, a large number of useful OERs have been contributed to the commons.

Additionally, note that the VET teachers considered the above mentioned methodology very positive for all the above reasons, but pointed out one more: with this methodology, when students finish their training, they not only obtain a certificate, but they have generated proof of their skills that are reflected on the Web and accessible to potential employers. The OERs generated by the students, on top of the advantages mentioned, leave a digital footprint that can be decisive in their employability possibilities. How does OER-enabled pedagogy affect the employability of students? It is a question that we leave open for future research.

Author Contributions: Conceptualization, F.S.V., J.E.M.G., A.T.I. and F.A.H.; methodology, F.S.V., J.E.M.G., A.T.I. and F.A.H.; software, F.S.V., J.E.M.G., A.T.I. and F.A.H.; validation, F.S.V., J.E.M.G., A.T.I. and F.A.H..; formal analysis, F.S.V., J.E.M.G., A.T.I. and F.A.H.; investigation, F.S.V., J.E.M.G., A.T.I. and F.A.H.; resources, F.S.V., J.E.M.G., A.T.I. and F.A.H.; data curation, F.S.V., J.E.M.G., A.T.I. and F.A.H.; writing—original draft preparation, F.S.V., J.E.M.G., A.T.I. and F.A.H.; writing-review and editing, F.S.V., J.E.M.G., A.T.I. and F.A.H.; visualization, F.S.V., J.E.M.G., A.T.I. and F.A.H.; supervision, F.S.V., J.E.M.G., A.T.I. and F.A.H.; project administration, F.S.V., J.E.M.G., A.T.I. and F.A.H. All authors have read and agreed to the published version of the manuscript.

Funding: This research received no external funding.

Institutional Review Board Statement: Not applicable.

Informed Consent Statement: Informed consent was obtained from all subjects involved in the study.

Data Availability Statement: The data presented in this study are available on request from the corresponding author.

Conflicts of Interest: The authors declare no conflict of interest.

\section{References}

1. Martínez-Morales, I.; Marhuenda-Fluixá, F. Vocational education and training in Spain: Steady improvement and increasing value. J. Vocat. Educ. Train. 2020, 72, 209-227. [CrossRef]

2. Lévy, P. Cibercultura: La Cultura en la Sociedad Digital; Anthropos Editorial: Barcelona, Spain, 2007. (In Spanish)

3. Lévy, P. Cibercultura: Informe al Consejo de Europa; Anthropos Editorial: Barcelona, Spain, 2011. (In Spanish)

4. Lévy, P. Inteligencia Colectiva: Por una Antropología del Ciberespacio; Biblioteca Virtual em Saúde: Washington DC, USA, 2004. (In Spanish)

5. Malone, T. Handbook of Collective Intelligence; MIT Center for Colletive Intelligence: Cambridge, MA, USA, 2012.

6. Ostrom, E. Governing the Commons. The Evolution of Institutions for Collective Action; Cambridge University Press: Cambridge, UK, 2017.

7. Dolsak, N.; Ostrom, E. The Commons in the New Millennium: Challenges and Adaptation; MIT Press: Cambridge, MA, USA, 2003.

8. Bauwens, M. The Political Economy of Peer Production. Available online: https://journals.uvic.ca/index.php/ctheory/article/ view /14464/5306 (accessed on 8 November 2021).

9. Bauwens, M. P2P and Human Evolution: Peer to Peer as the Premise of a New Mode of Civilization; Institute of Network Cultures: Amsterdam, The Netherlands, 2005.

10. ColaBoraBora. Available online: https:/ /www.colaborabora.org/colaborabora/sobre-el-procomun/ (accessed on 12 November 2021).

11. Jackson, D. Developing pre-professional identity in undergraduates through work-integrated learning. High Educ. 2017, 74, 833-853. [CrossRef]

12. Ibarra, H.; Petriglieri, J. Identity work and play. J. Organ. Chang. Manag. 2010, 23, 10-25. [CrossRef]

13. Dewane, C. Use of Self: A Primer Revisited. Clin. Soc. Work. J. 2006, 34, 543-558. [CrossRef]

14. Schwartz, S.J.; Luyckx, K.; Vignoles, V.L. Handbook of Identity Theory and Research; Springer Science \& Business Media: Berlin/Heidelberg, Germany, 2011.

15. Rosenblum, N.; Kluijtmans, M.; Ten Cate, O. Professional Identity Formation and the Clinician-Scientist: A Paradigm for a Clinical Career Combining Two Distinct Disciplines. Acad. Med. 2016, 91, 1612-1617. [CrossRef]

16. Balduzzi, M.M.; Egle, C.R. Representaciones sociales e ideología en la construcción de la identidad profesional de estudiantes universitarios avanzados. Rev. Intercont. Psicol. Educ. 2010, 12, 65-83. (In Spanish) 
17. Jackson, D. Re-conceptualising graduate employability: The importance of pre-professional identity. High. Educ. Res. Dev. 2016, 35, 925-939. [CrossRef]

18. Caballero, K.; Botía, A.B. El profesorado universitario como docente: Hacia una identidad profesional que integre docencia e investigación. REDU Rev. Docencia Univ. 2015, 13, 57-77. (In Spanish)

19. Cantón Mayo, I.; Téllez Martínez, S. Labor and profesional satisfaction of teachers. Rev. Lasallista Investig. 2016, 13, 214-226. [CrossRef]

20. Devís Devís, J.; Martos i Garcia, D.; Sparkes, A.C. Socialización y proceso de construcción de la identidad profesional del educador físico de una prisión. Rev. Psicol. Deporte 2010, 19, 73-88. (In Spanish)

21. Wenger, E. Communities of Practice: A Brief Introduction. 2011. Available online: https://scholarsbank.uoregon.edu/xmlui/ bitstream/handle/1794/11736/A/brief/introduction/to/CoP.pdf (accessed on 14 October 2021).

22. Schön, D.A. La Formación de Profesionales Reflexivos; Paidós: Barcelona, Spain, 1992. (In Spanish)

23. García-Vargas, S.; González, R.; Martín-Cuadrado, A. Influencia de las prácticas en el desarrollo de la identidad profesional de los estudiantes de educación social. Pedagog. Soc. Rev. Interuniv. 2016, 245-259. (In Spanish) [CrossRef]

24. Zabalza, M.A. El Prácticum y las prácticas externas en la formación universitaria. Rev. Práct. 2017, 1, 1-23. (In Spanish) [CrossRef]

25. Téllez Infantes, A. Identidad socioprofesional e identidad de género. Un caso empírico. Rev. Gaz. Antropol. 2002, 18, 12. (In Spanish) [CrossRef]

26. Moreno-Navarro, I. Trabajo, ideologías sobre el trabajo y culturas del trabajo. Rev. Iberoam. Relac. Labor. 1997, 3, 9-28. (In Spanish) [CrossRef]

27. Terranova, J.; López, L.; Cabrera, C. La práctica preprofesional integradora Concepción para la formación profesional en la carrera de educación. Opuntia Brava 2019, 11, 270-278. (In Spanish)

28. Government of Spain. Real Decreto 1529/2012, de 8 de Noviembre, por el que se Desarrolla el Contrato para la Formación y el Aprendizaje y se Establecen las Bases de la Formación Profesional Dual; BOE: Madrid, Spain, 2012. (In Spanish)

29. Government of Spain. Real Decreto 1147/2011, de 29 de Julio, por el que se Establece la Ordenación General de la Formación Profesional del Sistema Educativo; BOE: Madrid, Spain, 2011. (In Spanish)

30. Fowlie, J.; Forder, C. Pre-professional Identity Formation Through Connections with Alumni and the Use of LinkedIn. In Employability via Higher Education: Sustainability as Scholarship; Diver, A., Ed.; Springer: Cham, Switzerland, 2019.

31. Daniels, J.; Brooker, J. Student identity development in higher education: Implications for graduate attributes and work-readiness. Educ. Res. 2014, 56, 65-76. [CrossRef]

32. UNESCO. Available online: https://en.unesco.org/themes/building-knowledge-societies/oer (accessed on 9 November 2021).

33. Wickline, H. Open Educational Resources: Breaking the Lockbox on Education. Available online: https://hewlett.org/openeducational-resources-breaking-the-lockbox-on-education/ (accessed on 9 November 2021).

34. Wiley, D. Defining the "Open" in Open Content and Open Educational Resources. Available online: http:/ /opencontent.org/ definition/ (accessed on 14 October 2021)

35. Clinton-Lisell, V. Open Pedagogy: A Systematic Review of Empirical Findings. J. Learn. Dev. 2021, 8, 255-268.

36. Wiley, D. What Is Open Pedagogy? Available online: https:/ / opencontent.org/blog/archives/2975 (accessed on 14 October 2021)

37. Wiley, D.; Hilton, J.L., III. Defining OER-Enabled Pedagogy. Int. Rev. Res. Open Distrib. Learn. 2018, 19. [CrossRef]

38. Harel, I.; Papert, S. Constructionism; Ablex Publishing: Norwood, NJ, USA, 1991.

39. Bloom, B.S.; Engelhart, M.D.; Furst, E.J.; Hill, W.H.; Krathwohl, D.R. Taxonomy of Educational Objectives, Handbook I: The Cognitive Domain; David McKay Co Inc.: New York, NY, USA, 1956.

40. Churches, A. Bloom's taxonomy blooms digitally. Tech Learn. 2008, 1, 1-6.

41. Werth, E.; Williams, K. What Motivates Students About Open Pedagogy? Motivational Regulation Through the Lens of Self-Determination Theory. Int. Rev. Res. Open Distrib. Learn. 2021, 22, 34-54. [CrossRef]

42. Luo, T.; Hostetler, K.; Freeman, C.; Stefaniak, J. The power of open: Benefits, barriers, and strategies for integration of open educational resources. Open Learn. J. Open Distance e-Learn. 2020, 35, 140-158. [CrossRef]

43. Werth, E.; Williams, K. Exploring student perceptions as co-authors of course material. Open Prax. 2021, 13, 53-67. [CrossRef]

44. Williams, K.; Werth, E. Student Selection of Content Licenses in OER-enabled Pedagogy: An Exploratory Study. J. Copyr. Educ. Librariansh. 2021, 5. [CrossRef]

45. Al Abri, M.H.; Dabbagh, N. Testing the Intervention of OER Renewable Assignments in a College Course. Open Prax. 2019, 11, 195-209. [CrossRef]

46. Pereira Pérez, Z. Los diseños de método mixto en la investigación en educación: Una experiencia concreta. Rev. Electrónica Educ. 2011, 15, 15-29. Available online: https:/ / www.redalyc.org/pdf/1941/194118804003.pdf. (accessed on 20 November 2021). (In Spanish). [CrossRef]

47. Christ, T. A Recursive Approach to Mixed Methods Research in a Longitudinal Study of Postsecondary Education Disability Support Services. J. Mix. Methods Res. 2007, 1, 226-241. [CrossRef]

48. Dellinger, A.; Leec, N. Toward a Unified Validation Framework in Mixed Methods Research. J. Mix. Methods Res. 2007, 1, 309-332. [CrossRef]

49. Creswell, J. Mixed Methods Research: State of the Art. Available online: https://sitemaker.umich.edu/creswell.workshop/files/ (accessed on 11 October 2021). 
50. Spanish Ministry of Education. ORDEN de 29 de Julio 2009, de la Conselleria de Educación, por la que se Establece para la Comunitat Valenciana el Currículo del Ciclo Formativo de Grado Medio Correspondiente al título de Técnico en "Microcomputer Systems and Networks"; Boletín Oficial de la Comunidad Valenciana: Valencia, Spain, 2009. (In Spanish)

51. Gamboa, J.; Moso, M. Observatorio de la Formación Profesional en España. Informe Anual 2020; Fundación Bankia por la Formación Dual: Madrid, Spain, 2020. (In Spanish)

52. Rodríguez, C.; Inda, M.; Fernández, C.M. Influence of social cognitive and gender variables on technological academic interest among Spanish high-school students: Testing social cognitive career theory. Int. J. Educ. Vocat. Guid. 2016, 16, 305-325. [CrossRef]

53. García-Holgado, A.; Verdugo-Castro, S.; González, C.; Sánchez-Gómez, M.C.; García-Peñalvo, F.J. European Proposals to Work in the Gender Gap in STEM: A Systematic Analysis. IEEE Rev. Iberoam. Tecnol. Aprendiz. 2020, 15, 215-224. [CrossRef]

54. Mertens, D. Transformative Paradigm: Mixed Methods and Social Justice. J. Mix. Methods Res. 2007, 1, 212-225. [CrossRef]

55. García-Vargas, S.; Martín-Cuadrado, A.; Medina, A.; González, R.; Leví, G.; Holgueras, A. La identidad profesional del educador social y la formación práctica. In Proceedings of the XIII Symposium Internacional Sobre el Prácticum y las Prácticas en Empresas en la Formación Universitaria. Documentar y Evaluar la Experiencia de los Estudiantes en las Prácticas, Poio, Spain, 29 Juny-1 July 2015; Raposo-Rivas, M., Muñoz Carril, P.C., Zabalza Cerdeiriña, M.A., Martínez Figueira, M.E., Pérez Abellás, A., Eds.; Andavira: Santiago de Compostela, Spain, 2015; pp. 1009-1023.

56. García-Vargas, D.; Martín-Cuadrado, A.; González Fernández, R. Procedimientos innovadores utilizados en las prácticas externas para el desarrollo de la identidad profesional. Rev. Práct. 2018, 3, 41-59. [CrossRef] 